УДК 551.41

\title{
МОРСКАЯ ГРАНИЦА В ПРИБРЕЖНО-МОРСКОМ ПРИРОДОПОЛЬЗОВАНИИ И ВАРИАНТ ЕЕ ВЫДЕЛЕНИЯ ПО ГЛУБИНЕ
}

\author{
Сорокин П. С.
}

\author{
ФГБУН Тихоокеанский институт географии ДВО РАН, г. Владивосток \\ E-mail: paveleco@mail.ru
}

\begin{abstract}
Проведен анализ существующих подходов и нормативных актов по определению границы морской части прибрежно-морского природопользования. Выяснено, что, несмотря на наличие многочисленных определений прибрежной зоны, универсальных границ в направлении моря нет. Для целей управления морской деятельностью, т. е. прибрежным и океаническим природопользованием, становится недостаточным классическое определение прибрежной зоны из-за большей зависимости от пространства суши. Поэтому предлагается использовать термин «прибрежно-морская зона» с более широким определением, включающим, помимо территориальных, береговые и акваториальные структуры. Границы прибрежно-морской зоны могут устанавливаться в зависимости от целей исследования. В нашем исследовании предлагается установить такую границу по глубине, которая рассматривается нами как фактор, ограничивающий хозяйственную деятельность человека в море.
\end{abstract}

Ключевые слова: прибрежно-морское природопользование, хозяйственная деятельность, прибрежная зона, морская граница.

DOI: $10.34078 / 1814-0998-2021-1-66-74$

\section{ВВЕДЕНИЕ}

Прибрежно-морская зона, под которой следует понимать пространство активного взаимодействия моря и суши, состоит из морского берега, береговой линии и берегового подводного склона (Айбулатов, 2004). Для человека это пространство является одновременно местом его проживания и деятельности. Здесь сосредоточены объекты и виды природопользования, промышленности, туризма, рыбного и сельского хозяйства, военно-оборонного комплекса и т. д. Разнообразие видов природопользования часто приводит к конфликтам за использование пространства этой зоны как на суше, так и в море, в т. ч. устьевой ее части. Основная доля общемирового улова рыбы (70-80\%) добывается именно в прибрежно-морской зоне (Ocean..., 2009; Marine..., 2016).

Определение пространственных лимитов прибрежно-морского природопользования обусловлено различными задачами, главной из которых является изучение и познание географических границ как основы географического районирования (Бакланов, 2018). Для выделения границ прибрежно-морской зоны на берегу и в море существуют различные подходы. Их в основном

(C) Сорокин П. С., 2021 три: 1) физико-географический - геологический, геоморфологический принцип выделения природных границ с учетом климатических и гидродинамических условий, 2) экосистемный и 3) условный, т. е. институциональный, основанный на договорных принципах деления акватории в интересах различных природопользователей и стран.

Основные причины различного определения морских границ заключаются в подходах исследователей (с позиции береговой геоморфологии, океанологии и т. п.) и значения пространственных ориентиров для функционирования определенных видов природопользования. Следует отметить, что многочисленные классификации прибрежной зоны в системе прибрежно-морского природопользования выделяют морские границы в большинстве случаев формально, т. е. на основе международных договоров (Глоссарий..., 2008). Поэтому иногда при такой делимитации границы не отражают реальную доступность и членение морского пространства для природопользования.

Цель настоящего исследования - обосновать идею классификации прибрежно-морского природопользования по его морской границе на основе глубины.

Основными задачами являются следующие:

1) показать влияние глубины на пространственное распределение морских видов хозяйственной деятельности; 
2) определить максимальную глубину, ограничивающую основные виды морской хозяйственной деятельности;

3) выделить зоны концентрации экономической активности в море.

\section{МАТЕРИАЛ И МЕТОДЫ}

Материалом для анализа информации о существующих принципах выделения морской границы и глубины для функционирования отдельных видов природопользования стали научносправочные издания и методические публикации. Для более информативного представления о существующих принципах определения морских границ проведен краткий анализ зарубежной и отечественной литературы по управлению морской и прибрежно-морской деятельностью.

Данными для анализа активности использования морского пространства послужили сведения системы автоматизированного мониторинга всех типов плавсредств (http://www.marinetraffic.com/ $\mathrm{ru} /)$, представленные в виде карт плотности морского транспорта за 2017 г.

На примере сложившейся системы прибрежно-морского природопользования в дальневосточных и северных арктических морях России были рассмотрены основные виды хозяйственной деятельности и их морские границы с учетом глубины. Для этого использовался картографический материал (масштаб 1:10 000 000), в том числе интерактивная карта (https://map.openseamap.org/), a также научно-справочная литература.

\section{АНАЛИЗ ЛИТЕРАТУРЫ И ТЕРМИНОЛОГИЯ}

Мировой опыт в области зонирования морского пространства, а также построения отдельных схем морского пространственного планирования (МПП) и методов управления прибрежно-морским природопользованием изучен коллективом исследователей под руководством Ч. Н. Эйлера (Ehler, Douvere, 2009; Эйлер, 2014; Santos et al., 2019). Он включает в себя подробную информацию о процессе МПП от терминологии, принципов, оценки его реализации, правового законодательного статуса до перспектив его реализации в зарубежных странах.

Из 150 стран, имеющих выход в море, 66 имеют программы по разработке морских планов, в том числе морского пространственного планирования на государственном уровне (Santos et al., 2019). Например, в 2002 г. под управлением Государственной администрации по вопросам океанов КНР была разработана схема национального морского функционального зонирования, а также схемы зонирования приморских провинций и районов (Fang et al., 2011). В свою очередь в Китае такое управление на базе МПП стало основой для создания приморских экономических зон опережающего развития (Gao et al., 2017). В азиатских странах организуются рабочие совещания и мастер-классы по морскому планированию (например, APEC Training Workshop on Marine Spatial Planning and Marine Protected Areas Management). Следует отметить, что такое обучение в сфере МПП проходит в странах, где еще нет государственных морских программ ( $\mathrm{Lu}$ et al., 2015; Gissi, Suarez de Vivero, 2016).

$\mathrm{B}$ определениях прибрежно-морской зоны имеются значительные отличия, связанные с географическими особенностями морского пространства различных прибрежных государств. Например, в странах, где морские границы не могут достигать максимальной ширины континентального шельфа, их определяют по равному делению акваторий с соседними государствами, например, по проливу до 2 км от береговой линии. Помимо этого, прибрежно-морское природопользование не является основой для регламентации хозяйственной деятельности на пространстве контактной прибрежной зоны суша - море. Вопросы управления и контроля в прибрежноморской зоне возлагаются на отдельные государственные структуры и на соответствующие законодательные акты: водное, земельное законодательство, правила застройки, санитарные требования и пр.

В настоящее время для большинства стран мира прибрежно-морское природопользование активно развивается на базе научных представлений о природопользовании. Например, в виде системы пространственного управления природопользованием, которая базируется на следующих компонентах (Santos et al., 2019):

1) экосистемном управлении (ecosystem-based management) - комплексном подходе в определении устойчивости функционирования природных экосистем и снижения воздействия от деятельности человека;

2) морском природопользовании (sea use management) - аналоге территориального природопользования для управления деятельностью на морском пространстве при соблюдении экосистемных требований по сохранению морской природной среды. Здесь для планирования деятельности используются экосистемные принципы в целях исключения конфликтных ситуаций;

3) морском пространственном планировании (marine spatial planning) - общественном процессе анализа деятельности человека на морских акваториях для определения баланса между развитием экономики и общества через политический процесс (Ehler, Douvere, 2009). МПП является элементом морского природопользования. Например, для европейских стран - часть комплексной морской политики, обеспечивающей устойчивое и рациональное управление морской деятельностью (Колесникова, 2018); 
4) морском зонировании (ocean zoning) - действенном инструменте МПП, позволяющем через членение и картирование морских регионов сформировать конкретные стратегии прибрежноморского природопользования.

\section{РЕЗУЛЬТАТЫ И ИХ ОБСУЖДЕНИЕ}

В общем представлении типы морских границ можно систематизировать по принципам их выделения, обусловленные:

1) геолого-геоморфологическими факторами;

2) экосистемными характеристиками;

3) возможностями и условиями природопользования;

4) юридическими (оформленными в законодательных и нормативных документах).

Учитывая отечественный и зарубежный опыт в области прибрежно-морского природопользования, следует признать, что границы прибрежно-морской зоны не имеют обязательного определения и могут устанавливаться в зависимости от целей исследования (Гринфельдт, 2016). В географических работах преимущественно используют геоморфологическое определение (например, по О. К. Леонтьеву, 1961) с выделением берега и «берегового склона», т. е. его подводного продолжения (Лымарев, 2000). В экономических исследованиях эта зона представляет собой контактную геосистему с участками суши и водного пространства, вовлеченными напрямую или косвенно в хозяйственную деятельность (Бакланов и др., 2018).

Анализ мировой литературы по данной тематике, проведенный коллективом ученых (Глоссарий..., 2008), показывает преобладающее использование термина «береговая зона» в прибрежно-морском природопользовании, не уделяя отдельного внимания классификации его морской части.

Прибрежная зона включает: прибрежные воды, береговую линию, прибрежную часть суши, береговую часть суши (Плинк, Гогоберидзе, 2003). По представлениям большинства исследователей-береговедов, верхняя граница прибрежной зоны определяется по линии максимального, ежегодно повторяющегося заплеска прибоя (Леонтьев, Рычагов, 1979; Глоссарий..., 2008; Основные..., 2009). По мнению других авторов, прибрежная зона может быть представлена в 3-мерном формате в пределах высот от 200 м на суше и 200 м глубины в море (Голубев, 2011). Ширина прибрежно-морской зоны, по оценкам отдельных исследователей, может достигать 200 км в сторону моря и суши (Von Bodungen, Turner, 2001). Для туризма и приморского сельского хозяйства она не превышает 1 км, а для прибрежного судоходства, рыболовства она простирается на 150 км от берега в зависимости от степени развития сопутствующей инфраструктуры. Что же касается создания и развития береговой инфраструктуры для морских видов хозяйственной деятельности, то территориальное пространство для этого будет безусловно значительно меньше по сравнению с морским.

Существуют различные биотопические классификации морских зон - экосистемные (биономические), основанные на закономерностях распределения обитателей морского пространства и морского дна в зависимости от глубины, освещенности и температуры. В Мировом океане отмечается вертикальная зональность распределения живых организмов. Глубина ограничивает распространение донных растительных организмов и является основой для дифференциации морской биоты. Такая зональность и зависимость четко прослеживается для водорослей макрофитов и обитателей прибрежных акваторий. Гидробиологами выделены две экологические области: пелагиаль (толща воды) и бенталь (дно). В зависимости от глубины бенталь составляют следующие зоны: литоральная (до 200 м), батиальная (до 2500 м), абиссальная (до 6000 м) и ультраабиссальная (глубже 6000 м) (рис. 1).

С позиции геологии и геоморфологии прибрежная зона может рассматриваться по характеристикам рельефа: морфологическая (по крутизне берега, высотности); структурная; динамическая и т. п. Морское продолжение этой зоны - континентальный шельф. Основные районы рыболовства сосредоточены в пределах материкового шельфа и склона (Мельников, 1991). Граница шельфа располагается на глубине 200-250 м, а материкового склона на глубине 2500-3000 м (рис. 2). Высокой биопродуктивности шельфов способствует материковый сток, а также подъем и перемешивание в районы шельфа глубинных вод с большими концентрациями биогенных веществ.

Представляя возможные морские границы, следует отметить что, кроме природных, существуют и условные. К таковым относится, например, граница санитарной ответственности (СанПиН 2.1.5.2582-10). Она установлена для регламентации хозяйственной деятельности в море и составляет не менее 10 км. Для береговых природопользователей эта граница отмеряется в направлении моря и суши на 2 км. Максимальная зона санитарной охраны района водопользователя - 22 км (12 морских миль). Эта граница устанавливается для природопользователей, закрепленных за конкретными морскими районами в пределах российских территориальных вод. В прибрежные воды сбрасываются неочищенные сточные воды от береговых объектов: городских, промышленных и сельскохозяйственных, а также в результате морской добычи нефти и природного газа. 


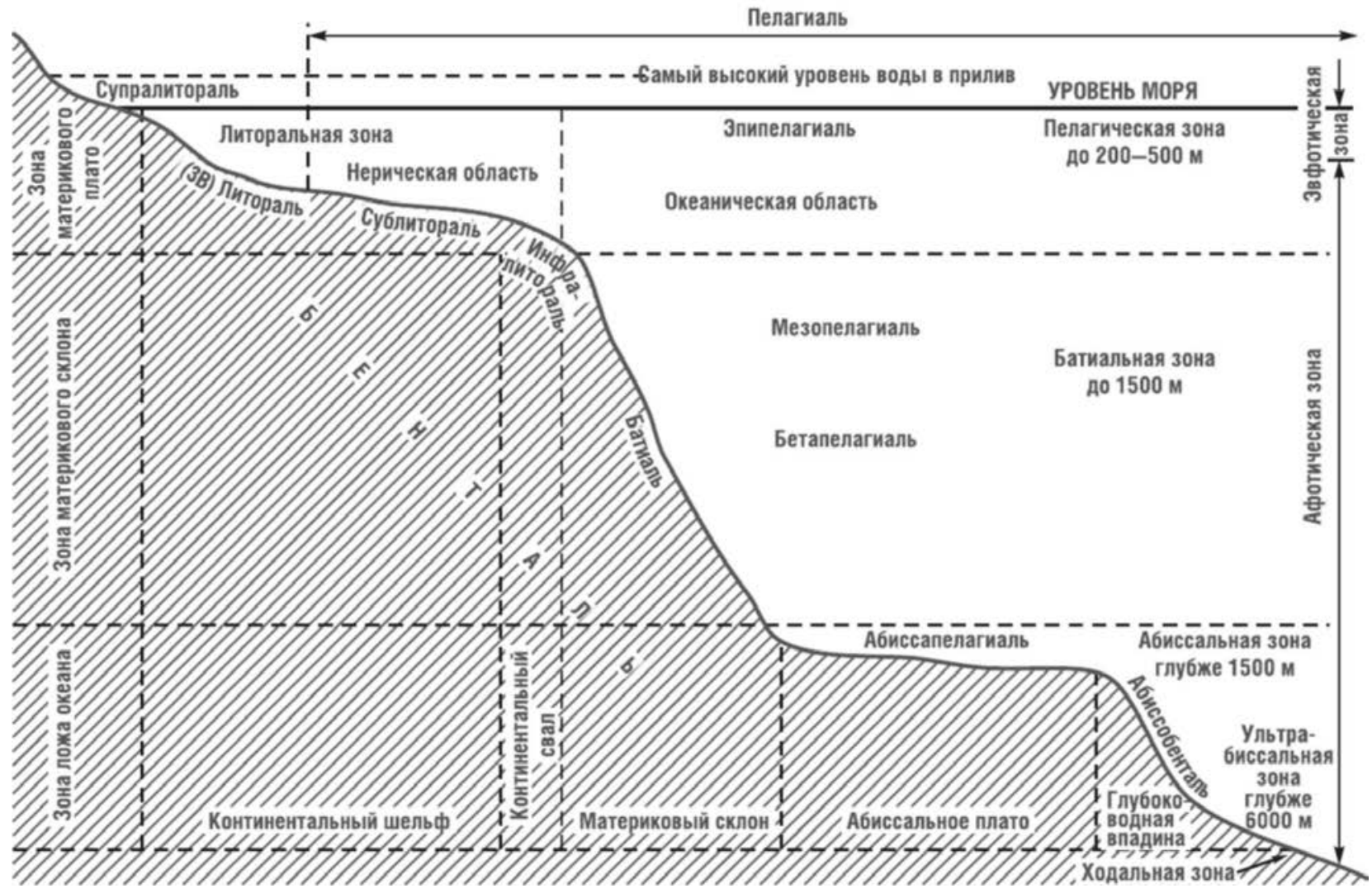

Puc. 1. Типы морских границ, связанные со структурными характеристиками морской экосистемы (Дроздов, 2011)

Fig. 1. Marine border types linked with their marine ecosystem structures (Drozdov, 2011)

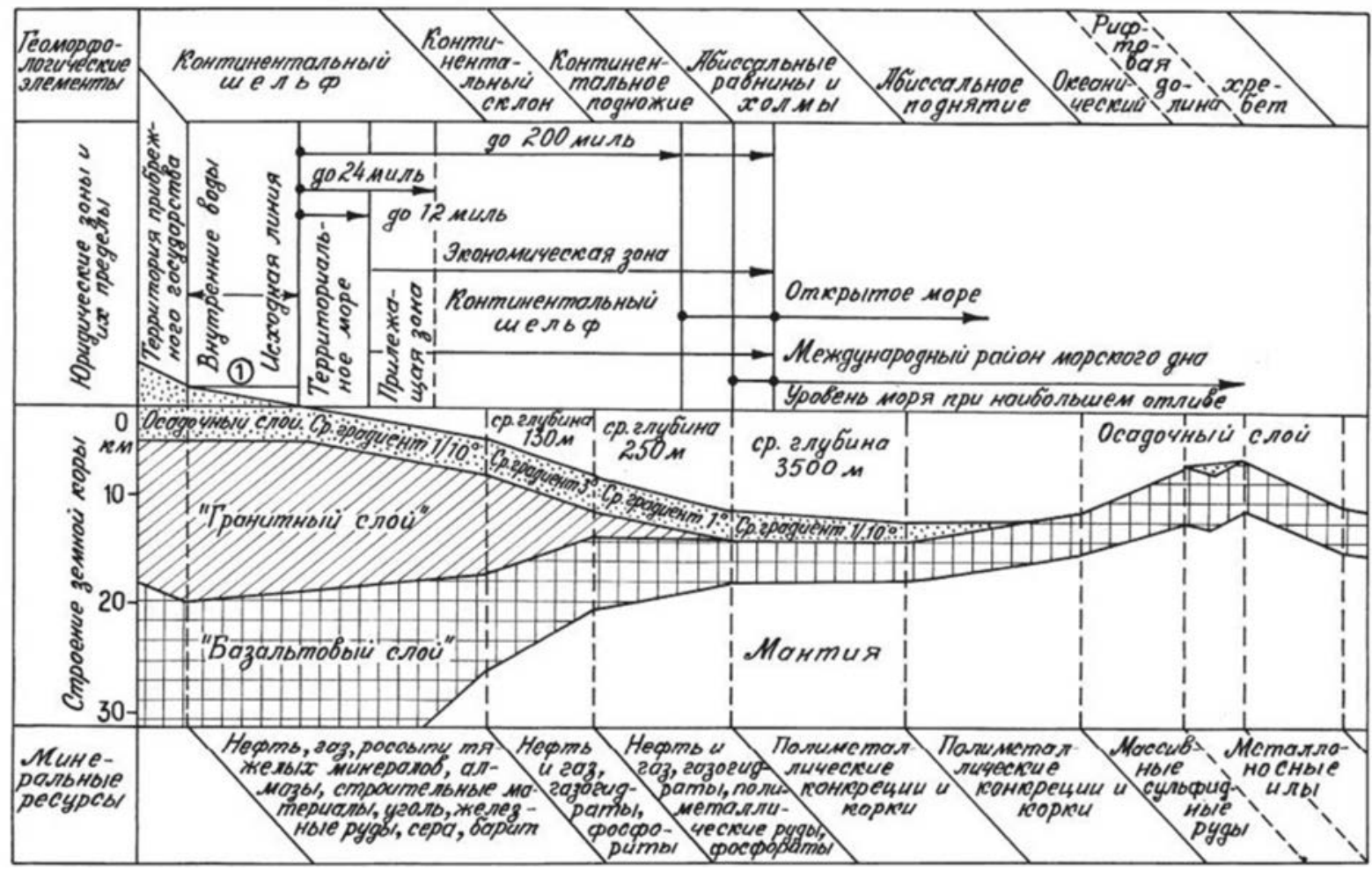

Puc. 2. Типы морских границ, связанных с геолого-геоморфологическими факторами, и их взаимосвязь с юридическими (Куприн, 2014)

Fig. 2. Marine borders types by geological and geomorphological factors and their relation with legal state zones (Kuprin, 2014) 
Очевидно, что несоблюдение этих требований приводит к конфликтным ситуациям и экологическим проблемам.

Таким образом, определение границ прибрежно-морской зоны опирается на геоморфологические, экосистемные, геологические, а также на договорные принципы конвенции о границах внутренних и территориальных вод. Договорные, юридические границы почти совпадают с геоморфологической границей континентального подножия, где сосредоточены запасы углеводородов (см. рис. 2). Согласно морской конвенции, максимальная граница ответственности хозяйственной деятельности в море простирается до 370 км от берега (Конвенция..., 1982). Граница территориальных вод установлена $\mathrm{OOH}$ в 1977 г. и соответствует 7.5\% площади Мирового океана.

Что касается классификации морской границы для целей прибрежно-морского природопользования, то она основывается на границе исключительной экономической зоны государства, а по геоморфологической позиции - по ширине морского шельфа. Общеизвестно, что ресурсы шель- фа Мирового океана неоднородны. Они распределены на различных глубинах, кроме этого административная граница различная, поэтому глубина моря, на наш взгляд, выступает вполне обоснованным критерием выделения морских лимитов для прибрежно-морского природопользования.

По представлениям автора была составлена таблица морских видов хозяйственной деятельности и инфраструктуры преимущественно в районе исследования с указанием глубины как ограничивающего фактора прибрежно-морского природопользования (см. таблицу). Приведенные в ней значения максимальной глубины, в том числе, как и перечень морских природопользователей, не являются абсолютными и исчерпывающими. Таблица демонстрирует широкий спектр глубин, ограничивающих осуществление отдельных направлений морской хозяйственной деятельности, и не претендует на универсальность.

Процесс природопользования осуществляется в природно-социально-экономических системах, состоящих из трех подсистем. Экономические, экологические и социальные результаты прояв-

Таблица. Распределение некоторых видов хозяйственной деятельности в море по максимальной глубине

Table. Distribution of several marine nature uses by depth

\begin{tabular}{|c|c|}
\hline Вид хозяйственной деятельности & Глубина макс., м \\
\hline \multicolumn{2}{|l|}{ 1. Портовая инфраструктура } \\
\hline \multirow{2}{*}{$\begin{array}{l}\text { 1.1. Терминалы, причалы, пристани (РД 31.3.01.01-93) } \\
\text { (глубина портов для пассажирских судов: 5-6.5 м; } \\
\text { для судов грузоподъемностью до } 100 \text { тыс. т: > } 16 \text { м) } \\
\text { 1.2. Судоремонтные и судостроительные организации }\end{array}$} & 20 \\
\hline & 20 \\
\hline 2. Дноуглубительные работы (РД 31.74.09-96) & 24 \\
\hline 3. Судоходство (перевозки грузов и населения) & Не ограничены \\
\hline 4. Добыча и разведка нефти и газа (на примере Мексиканского залива) & 2450 \\
\hline 5. Добыча песка и гравия & 20 \\
\hline \multicolumn{2}{|l|}{ 6. Подводные коммуникации } \\
\hline \multirow{4}{*}{$\begin{array}{l}\text { 6.1. Подводные линии связи (по Портнову, 2002) } \\
\text { 6.2. Газопроводы (по примеру Мексиканского залива) } \\
\text { 6.3. Магистральные водопроводы (между Турцией и Кипром) } \\
\text { 6.4. Силовые провода (по примеру Средиземного моря) }\end{array}$} & 7500 \\
\hline & 2530 \\
\hline & 280 \\
\hline & 1485 \\
\hline \multicolumn{2}{|l|}{ 7. Промысел и разведение морских биоресурсов } \\
\hline \multirow{6}{*}{$\begin{array}{l}\text { 7.1. Прибрежное рыболовство (сети) } \\
\text { 7.2. Прибрежное рыболовство (донными тралами) } \\
\text { 7.3. Прибрежное рыболовство (ловушки) } \\
\text { 7.4. Любительское рыболовство (на маломерных судах и лодках) } \\
\text { 7.5. Любительское рыболовство (с берега) } \\
\text { 7.6. Марикультура }\end{array}$} & 200 \\
\hline & 2500 \\
\hline & 1200 \\
\hline & 60 \\
\hline & 10 \\
\hline & 50 \\
\hline \multirow{4}{*}{$\begin{array}{l}\text { 8. Морские рекреационные и охраняемые участки } \\
\text { 8.1. Пляжная рекреация } \\
\text { 8.2. Подводная охота } \\
\text { 8.3. Подводное плавание (легководолазное снаряжение) }\end{array}$} & 50 \\
\hline & 3 \\
\hline & 12 \\
\hline & 40 \\
\hline 9. Водолазные работы & 160 \\
\hline 10. Военно-морской флот (погружения подводных лодок) & 1000 \\
\hline
\end{tabular}


ляются на выходе из этой системы. Авторский вариант выделения видов прибрежно-морского природопользования выполнен по пространственному классификационному критерию принципу расположения природопользователя от берега в сторону моря, т. е. по одному из трех признаков классификации «природопользования» Ю. Л. Мазурова (Систематизация..., 2015).

Различные виды морской хозяйственной деятельности зависят от глубины по-разному. Рассмотрим некоторые из направлений использования морского пространства, представленных в таблице.

Например, при проектировании портовопромышленных комплексов глубина акватории является значимым параметром для перспектив использования морского пространства, основой по расширению спектра услуг и как следствие региональных связей. Уменьшение глубины (вследствие осадконакопления или замусоривания дна) приводит к материальным и временнымм затратам на дноуглубительные работы, а также нарушению графика работы пассажирских или грузовых передвижений.

Добыча углеводородов, например, на охотоморских месторождениях, осуществляется преимущественно на глубинах 100-400 м (северная часть), а у берегов о. Сахалин эта отметка на некоторых морских участках добычи достигает 1000 м. Это связано с различной шириной материкового и островного шельфа. Из-за того, что мировые запасы углеводородов распределены по морскому дну неравномерно по глубине, применяются различные технологии и способы транспортировки, типы буровых установок, что в конечном счете сказывается на рентабельности производства. Данное обстоятельство является основанием проведения отдельного морского зонирования по запасам углеводородов по глубинам.

Глубина моря влияет на распределение гидробионтов и, как следствие, на объемы их промышленного вылова рыбодобывающим флотом в дальневосточных и арктических морях. В настоящее время эффективный вылов зависит от технического оснащения, но распределение промысловых концентраций гидробионтов (т. е. допустимого вылова без ущерба для популяции) имеет четкую приуроченность к конкретным глубинам. Это подтверждается и хорошо прослеживается на информационных картах базы передвижения морского транспорта (marine traffic). Рыболовные суда в дальневосточных морях России распространены повсеместно. Более плотные их скопления отмечаются на морских участках с глубинами 200-400 м (Сорокин, 2020). На годовых картах marine traffic для Охотского моря наиболее биопродуктивные рыбопромысловые районы западной Камчатки совпадают с участками акваторий, характеризующимися наивысшей плотностью морского транспорта. На глубинах более 1000 м нахождение рыболовных плавсредств отмечается редко.

Перевозка крупнотоннажных грузов осуществляется вдоль тихоокеанского и арктического побережья России, не выходя за границы каботажного плавания и концентрируясь на акваториях с глубинами менее 200 м. Международные транзитные пути осуществляются по принципу кратчайшего расстояния между пунктами отправления и прибытия, поэтому глубина акватории здесь не является фактором, ограничивающим морские грузоперевозки. Сравнивая распределение типов морских плавсредств (по картам marine traffic), следует отметить, что распределение рыбодобывающего флота имеет четкую связь с глубиной моря, в то время как для осуществления различных морских перевозок она не учитывается.

\section{ЗАКЛЮЧЕНИЕ}

Выделение морских границ, в том числе максимальных глубин прибрежно-морского природопользования, является базовым элементом определения функциональных зон при разработке схем морского пространственного планирования. Разнообразие морских видов природопользования зависит от протяженности морского шельфа и спектра природных ресурсов, которые возможно использовать в хозяйственной деятельности. Глубина акваторий является фактором, ограничивающим прибрежно-морское природопользование. Она также может быть рассмотрена как критерий при разработке классификации природопользования в море.

На примере акваторий дальневосточных морей РФ определено, что максимальное скопление и вариация морского транспорта наблюдаются в зоне каботажного плавания (до 200 км от берега). Наибольшие глубины (более 1000 м) не являются препятствием для транзитных путей различных видов морского транспорта, но ограничивают добычу биологических и минеральных ресурсов.

Выполненная работа представляет собой основу для классификации прибрежно-морского природопользования по глубине для отдельных районов Мирового океана. В этой статье заложены идея и доказательство утверждения автора, которое бесспорно получит дальнейшее более детальное исследование по заявленной тематике. Автор будет признателен за получение замечаний от читателей и предложений по заявленной тематике.

Работа выполнена в рамках научного проекта № 18-05-80006. 


\section{ЛИТЕРАТУРА}

Айбулатов Н. А. О терминологии в береговой зоне моря // Прибрежная зона моря: морфолитодинамика и геоэкология. Калининград : Изд-во КГУ, 2004. С. 62-65.

Бакланов П. Я., Ермошин В. В., Ганзей К. С., Качур A. Н., Жариков В. В., Нгуен Ван Кы, Дао Динь Чам. Устойчивое прибрежно-морское природопользование в тихоокеанской России и Вьетнаме // Геосистемы в Северо-Восточной Азии. Владивосток. Типы, современное состояние и перспективы развития. 2018. C. 589-593.

Бакланов П. Я. Морское пространственное планирование: теоретические аспекты // Балтийский регион. 2018. Т. 10, № 2. С. 76-85.

Берега / П. А. Каплин, О. К. Леонтьев, С. А. Лукьянова, Л. Г. Никифоров. Москва : Мысль, 1991. С. 8.

Глоссарий по Кадастру береговой (прибрежной) зоны / Г. Г. Гогоберидзе, В. А. Жамойда, Е. Н. Нестерова, Д. В. Рябчук, М. А. Спиридонов. Санкт-Петербург : РГГМУ, 2008. 95 с.

Голубев Г. Н. Основы геоэкологии : учебник. Москва : КноРус, 2011. С. 222.

Гринфельдт Ю. С. Береговая зона Мирового океана: особенности природопользования и геоэкологические проблемы // Глобальный научный потенциал. Природопользование и региональная экономика. 2016. № 9 (66). С. 30-34.

Дроздов В. В. Общая экология. Санкт-Петербург : РГГМУ, 2011. $412 \mathrm{c.}$

Колесникова М. Морское пространственное планирование в ЕС. ИЕ РАН. Аналитическая записка № 13. 2018 (№ 109). 6 c. (www.instituteofeurope.ru/ publications/analytics)

Конвенция Организации Объединенных Наций по морскому праву, 1982 (Ратифицирована ФЗ РФ от 26.02.1997 г. № 30-Ф3).

Куприн П. Н. Введение в океанологию. Москва : Изд-во МГУ, 2014. 618 с.

Леонтьев О. К. Основы геоморфологии морских берегов. Москва : МГУ, 1961. 420 с.

Леонтьев О. К., Рычагов Г. И. Общая геоморфология. Москва : Высшая школа, 1979. 287 с.

Лымарев В. И. Береговое природопользование: вопросы методологии, теории и практики. СанктПетербург : РГГМУ, 2000. 168 с.

Мельников В. Н. Устройство орудий лова и технология добычи рыбы. Москва : Агропромиздат, 1991. C. 23.

Основные концепции современного берегопользования. Санкт-Петербург : РГГМУ, 2009. Т. 1. 217 с.

Плинк Н. Л., Гогоберидзе Г. Г. Политика действий в прибрежной зоне. Санкт-Петербург : РГГМУ, 2003. $226 \mathrm{c}$.

Портнов Э. Л. Оптические кабели связи: конструкции и характеристики. Москва : Горячая линия - Телеком, 2002. 232 с.
РД 31.3.01.01-93. Руководство по технологическому проектированию морских портов. Ч. I (Дата введения 1994-01-01).

РД 31.74.09-96. Нормы на морские дноуглубительные работы (Дата введения 1997-01-01).

СанПиН 2.1.5.2582-10 «Санитарно-эпидемиологические требования к охране прибрежных вод морей от загрязнения в местах водопользования населения».

Систематизация и типологическая классификация природопользования / под общ. ред. М. В. Слипенчука. Москва : Изд-во МГУ, 2015. 72 с.

Сорокин П. С. Типы морских границ и их функции в различных видах прибрежно-морского природопользования // Геосистемы Северо-Восточной Азии: природные, природно-ресурсные, социальные и хозяйственные структуры территорий. Владивосток : ТИГ ДВО РАН, 2020. С. 354-360.

Эйлер Ч. Н. Обзор мирового опыта в области морского пространственного планирования / пер. С. Ю. Фомин. 2014 (WWF). 136 c.

Ehler Ch., Douvere F. Marine spatial planning: A stepby-step approach toward ecosystem-based management. Intergovernmental Oceanographic Commission and Man and the Biosphere Program. IOC Manual and Guides No. 53, ICAM Dossier No. 6. Paris : UNESCO, 2009. P. 22.

Fang Q., Zhang R., Zhang L., Hong H. Marine functional zoning in China: Experience and prospects // Coastal Management. 2011. 39:6. P. 656-667.

Gao J., Liu C., He G., Wang T. Study on the management of marine economic zoning: An integrated framework for China // Ocean \& Coastal Management. 2017. 149. P. 165-174.

Gissi E., Suarez de Vivero J. L. Exploring marine spatial planning education: Challenges in structuring transdisciplinarity // Marine Policy. 2016. 74. P. 43-57.

Lu W.-H., Liu J., Xiang X.-Q., Song W.-L., McIlgorm A. A comparison of marine spatial planning approaches in China: Marine functional zoning and the marine ecological red line // Marine Policy. 2015. 62. P. 94-101.

Marine spatial planning for enhanced fisheries and aquaculture sustainability. Its application in the Near East / Geoffery J. Meaden. FAO fisheries and aquaculture. Technical Paper 604. Rome, 2016. 90 p.

Ocean and coastal ecosystem-based management: Implementation handbook. Environmental Law Institute, Washington, D. C., 2009.

Santos C. F., Ehler Ch. N., Agardy T., Andrade F., Orbach M. K., Crowder L. B. Marine spatial planning. 2019. Elsevier Ltd. World seas : An environmental evaluation, Ch. 30. P. 572-592. https://doi.org/10.1016/ B978-0-12-805052-1.00033-4

Von Bodungen B., Turner R. K. (Eds.). Science and integrated coastal management. Berlin : Dahlem University Press, 2001. 378 p. 


\title{
MARINE BORDER IN COASTAL MANAGEMENT AND MARINE DELIMITATION BY DEPTH
}

\author{
P. S. Sorokin
}

\section{Pacific Geographical Institute, FEB RAS, Vladivostok}

\begin{abstract}
The existing approaches and regulations for the determination of the marine boundaries of the part of coastal-marine natural management are analyzed. There are no uniform boundaries in the direction toward the sea, despite the presence of numerous definitions of the coastal zone. For the purposes of maritime activities management, i.e. coastal and oceanic natural management, the geomorphological definition of the coastal zone becomes insufficient due to the greater dependence on the land space. Therefore, it is proposed to use the term "coastal-marine zone" with a broader definition, including, in addition to territorial, coastal and aquatic structures. The coastal-sea zone boundaries can be established depending on the research objectives. In our research, we suggest to establish this kind of depth boundary, considering it a limiting factor of marine economic activities..
\end{abstract}

Keywords: coastal management, economic activity, coastal zone, marine delimitation.

\section{REFERENCES}

Aybulatov, N. A., 2004. On the Terminology in the Marine Coastal Zone, Marine Coastal Zone, Morpholytodinamics and Geoecology. Kaliningrad, KSU. 62-65 [In Russian].

Baklanov, P. Ya., 2018. Marine Spatial Planning: Theoretical Aspects, The Baltic Region. 10, 2, 76-85. doi: 10.5922/2079-8555-2018-2-5 [In Russian].

Baklanov, P. Ya., Yermoshin, V. V., Ganzey, K. S., Kachur, A. N., Zharikov, V. V., Nguyen Van Ky, Dao Dinh Cham., 2018. Sustainable Coastal and Marine Nature Management in Pacific Russia and Vietnam. Geosystems in Northeast Asia. Types, Current State, and Development Prospects. Vladivostok, 589-593 [In Russian].

Basic Concepts of the Modern Coastal Zone Management, 2009. St. Petersburg, I [In Russian].

Ehler, Ch. N., 2014. Marine Spatial Planning: Review of World Experience / Translated by S. Yu. Fomin. (WWF) [In Russian].

Ehler, Ch., Douvere, F., 2009. Marine Spatial Planning: A Step-by-Step Approach Toward Ecosystem-Based Management. Intergovernmental Oceanographic Commission and Man and the Biosphere Program. IOC Manual and Guides No. 53, ICAM Dossier No. 6. Paris, UNESCO. 22.

Fang, Q., Zhang, R., Zhang, L., Hong, H., 2011. Marine Functional Zoning in China: Experience and Prospects, Coastal Management. 39:6, 656-667.

Gao, J., Liu, C., He, G., Wang, T., 2017. Study on the Management of Marine Economic Zoning: An Integrated Framework for China, Ocean \& Coastal Management. 149, 165-174.

Gissi, E., Suarez de Vivero, J. L., 2016. Exploring Marine Spatial Planning Education: Challenges in Structuring Transdisciplinarity, Marine Policy. 74, 43-57.

Glossary on the Coastal Zone Cadastre / G. G. Gogoberidze, V. A. Zhamoida, E. N. Nesterova, D. V. Ryabchuk, M. A. Spiridonov, 2008. St. Petersburg, RSHU [In Russian].
Golubev, G. N., 2011. Geoecology, Moscow, KnoRus, 222 [In Russian].

Grinfeldt, Yu. S., 2016. Coastal Zone of the World Ocean: Nature Management Aspects and Geoecological Problems, Global Scientific Potential. Nature and Regional Economics. 9 (66), 30-34 [In Russian].

Drozdov, V. V., 2011. General Ecology. St. Petersburg, RSHU [In Russian].

Kolesnikova, M., 2018. Marine Spatial Planning in EU. IE RAS. Analytical Report, 13, 109 (www.instituteofeurope.ru/publications/analytics).

Kuprin, P. N., 2014. Introduction into Oceanology. Moscow, MSU [In Russian].

Leontyev, O. K., 1961. Coastal Geomorphology. Moscow, MSU [In Russian].

Leontyev, O. K., Rychagov, G. I., 1979. General Geomorphology. Moscow, Vysshaya Shkola.

Lu, W.-H., Liu, J., Xiang, X.-Q., Song, W.-L., McIlgorm, A., 2015. A Comparison of Marine Spatial Planning Approaches in China: Marine Functional Zoning and the Marine Ecological Red Line, Marine Policy. 62, 94-101.

Lymarev, V. I., 2000. Coastal Zone Using: Aspects of Methodology, Theory, and Practice. St. Petersburg, RSHU [In Russian].

Meaden, G. J., Agular-Manjarrez, J., Corner, R. A., O’Hagen, A. M. 2016. Marine Spatial Planning for Enhanced Fisheries and Aquaculture Sustainability: Its Application in the Near East. FAO Fisheries and Aquaculture. Technical Paper 604. Rome doi: 10.13140/ RG.2.2.34295.42403.

Melnikov, V. N., 1991. Fishing Equipment and Fishery Technologies. Moscow, Agropromizdat.

Ocean and Coastal Ecosystem-Based Management: Implementation Handbook, 2009. Environmental Law Institute Washington, D. C.

Plink, N. L., Gogoberidze, G. G., 2003. Policy of Acting in the Coastal Zone. St. Petersburg, RSHU [In Russian]. 
Portnov, E. L., 2002. Optical Connection Cables: Design and Characteristics. Moscow, Hotline - Telecom [In Russian].

Regulatory Document 31.3.01.01-93: Process Planning of Sea Ports. Part I (Effective Date 1991-01-01) [In Russian].

Regulatory Document 31.74.09-96: Marine Dredging Norms (Effective Date 1997-01-01) [In Russian].

SanPiN 2.1.5.2582-10: Sanitary and Epidemiologic Requirements to Coastal Waters Protection against Pollution in Public Water-Use Spots [In Russian].

Santos, C. F., Ehler, Ch. N., Agardy, T., Andrade, F., Orbach, M. K., Crowder, L. B., 2019. Marine Spatial Planning. Elsevier Ltd. World Seas: An Environmental Evaluation. 30. 572-592 (https://doi.org/10.1016/B978-0-12805052-1.00033-4).
Science and Integrated Coastal Management, 2001. Eds. Von Bodungen, B., Turner, R. K. Berlin, Dahlem University Press.

Sea Shores / P. A. Kaplin, O. K. Leontyev, S. A. Lukyanova, L. G. Nikiforov, 1991. Moscow, Misl. 8 [In Russian].

Sorokin, P. S., 2020. Types of Marine Borders and Their Functions in Various Coastal-Marine Nature Uses, Geosystems in Northeast Asia: Nature, Natural Resources, Social and Economic Structures of the Territories. Vladivostok, PGI FEB RAS, 354-360 [In Russian].

Systematization and Typological of Nature Management, 2015. Ed.: M. V. Slipenchuk. Moscow, MSU [In Russian].

United Nations Convention on the Law of the Sea. UNCLOS : 1982 (Effective Date 1997-26-02) [In Russian]. 